\title{
Environmental Management in Small and Medium Scale Manufacturing Industries in Shah Alam
}

\author{
Mohd Rashdan Isa ${ }^{1}$, Omar Suliman Zaroog ${ }^{1}$, Krishnakumar Kalaiarasan $^{1}$ \\ ${ }^{1}$ Department of Mechanical Engineering, Universiti Tenaga Nasional, Kajang, 43000, Malaysia
}

\begin{abstract}
Being one of the biggest industrialized city in Malaysia with large urban settlements, Shah Alam has been prone to serious environmental issues in the last decades. The small and medium manufacturing industries generate severe environmental impact and it lags far behind compared to other industries and sectors in implementing Environmental Management due to various factors. This study is to evaluate environmental impacts of manufacturing and to examine the company behaviour towards Environmental Management, thus explore the available measures for Environmental Management by employing a Questionnaire survey. This paper summarizes and discusses the result of a survey on Environmental Management in Small and Medium Scale Manufacturing Industries in Shah Alam. The primary respondents were from different manufacturing sectors such as automotive, petroleum, chemicals, plastics, food production, metal manufacturing, wood, paper, leather, electrical, electronics, and general machinery. The results discuss the respondent's profile, subject's environmental management practices, their relations with stakeholders, and environmental awaren ess. $A$ thorough statistical analysis is carried out with the results obtained.
\end{abstract}

Keywords: Environmental, Manufacturing, Small and Medium Manufacturing Industries.

\section{Introduction}

Due to the increasing environmental awareness from the public, the legal requirements in line with local city council, Majlis Bandaraya Shah Alam's (MBSA) policies and regulations, Environmental Management (EM) is an integral part of large manufacturing industries in Shah Alam. In comparison with other large sectors, it lags far behind in implementing environmental management (EM).

The ISO 14001 standard is the most comprehensive standard for environmental risk management and is directly linked to the European Eco-Management and Audit Scheme (EMAS). Environmental Management is becoming an imperative tool in observing and preserving the environment. They are used globally by industries to identify, monitor and regulate possible environment effects. In fact, EM is now a business approach and requisite for some industry sectors. Implementation of EM policies provides a competent guidance for companies to concurrently develop, establish themselves and assess their business practices towards both business and environmental goals. EM means the management of the interaction and impact of human societies on the environment.

\section{Literature Review}

$\mathrm{EM}$ is an aspect that signifies the overall management structure that addresses the instantaneous and long-term effect of its services, products and processes to the environment. It was fragmented with the establishment of the British Standard 7750 (BS7750) by the United Kingdom. Later, the European Commission developed Ecomanagement and Audit System (EMAS) to provide a standard that could be acknowledged worldwide (H. H. Low 2015).

In 1993, the ISO 14001 series were introduced to aid industries to be both sustainable and environmental friendly to acknowledge internationally and sets out the steps to be taken by an organization to implement an effective EM. ISO 14001 standards were endorsed more than 100 countries as an international standard and written by consensus of about 50 countries (Perumal Puvanasvaran 2012).

EM System should be built on the Plan, Do, Check, Act" model to make sure that environmental problems are thoroughly recognized, controlled, and supervised. Using this approach will help to ensure that performance of the Environmental Management System progresses over time and that goals for implementing an EMS is in the first place (Philip J. Stapleton 2001).

EM improves quality, customer satisfaction, and production management (O. Boiral 2012) as well as enhances operational efficiency, help cost savings, promotes compliance assurance, improves relationship with regulators, reduces risks such as insurance costs (Homens 2011). EM provides very strong internal motivation, commitment of top management, communication with interest groups, stakeholder's involvement, accountabilities for environmental management (H.J.D. Vries 2012). Besides that, developments in productivity, competitiveness, business profitability, and green image are benefits of EM (P. Gonzalez 2008). Some of the major barriers for the implementation of Environmental Management are motivation, resource issues, and implementation concerns (The National Environmental Education \& Training Foundation 2001).

Top management is the key success factors in the implementation of EMS. The common critical success factors in implementing EMS ISO 14001 are leadership and support of the management, internal analysis, learning and training and sustainability (Ambika Zutshia 2004) as well as the employee empowerment, commitment of management, rewards, feedback, and review (Nalini 2004). 


\section{International Journal of Science and Research (IJSR) \\ ISSN (Online): 2319-7064}

Index Copernicus Value (2013): 6.14 | Impact Factor (2014): 5.611

\section{Methodology}

Questionnaire survey is the main methodology employed in this research which allows the gathering of large of number of data from a significant amount of population in easy and more economical way. The first stage of this survey is Questionnaire Design Process where the survey questionnaire was designed, pre-tested, and debugged. The following stage is Data Collection. Data was collected from 100 different manufacturing companies in Shah Alam, in which only 57 were identified to be SMEs. Once the data was collected, they were thoroughly, analysed using SPSS (Statistical Package for Social Sciences). Once the data is thoroughly analysed, some of the data were validated to prove their reliability using the Cronbach Alpha. Cronbach Alpha is a measure of internal consistency, that is, how closely related a set of items are as a group. It is considered to be a measure of scale reliability (UCLA, 2015).

\section{Result}

\subsection{Respondent Profile}

The response rate for this survey varied by industry from $7.02 \%$ to $24.56 \%$. The highest number of positive responses were from petroleum, chemicals, and plastics sector (14 responses) and the lowest were from automotive sector (4 responses). Table 1 represents the statistical analysis of respondents by their nature of business.

The questionnaires were mainly addressed to managers, assistant managers, supervisor, section heads, and environmental specialists or engineers that has adequate knowledge on Environmental Management policies and practices, especially ISO 14001.

\subsection{Environmental Management Practices}

When questioned on how the companies communicate with their employees regarding their environmental policy if they have any, most of the respondent's choose to have it posted at their facility (27 responses). The least favourite option was distributing to employees, which constitutes $7 \%$. A number of 12 respondents said that they don't communicate with their employees regarding this because they don't have any policy. The result is presented in Table 2 below

When a thorough cross tabulation done on EM policy communication from industry to industry, general machinery industry is found to be having 4 respondents without any environmental policy, followed by 3 electrical and electronics companies. The rest of the businesses had one respondent in this category with only automotive industry being an exclusion. Table 3 shows the EM policy communication result.

Table 1: Business nature by respondents

\begin{tabular}{|c|c|c|c|c|c|}
\hline \multicolumn{2}{|c|}{} & Frequency & Percent & $\begin{array}{c}\text { Valid } \\
\text { Percent }\end{array}$ & $\begin{array}{c}\text { Cumulative } \\
\text { Percent }\end{array}$ \\
\hline \multirow{7}{*}{$\begin{array}{c}\text { Automotive } \\
\begin{array}{c}\text { Chemicals, and } \\
\text { plastics }\end{array}\end{array}$} & 4 & 7.0 & 7.0 & 7.0 \\
\cline { 2 - 6 } & $\begin{array}{c}\text { Petroleum, } \\
\text { Food Production }\end{array}$ & 8 & 14.0 & 14.0 & 45.6 \\
\cline { 2 - 6 } & $\begin{array}{c}\text { Metal } \\
\text { Manufacturing }\end{array}$ & 6 & 10.5 & 10.5 & 56.1 \\
\cline { 2 - 6 } & $\begin{array}{c}\text { Wood, Paper, } \\
\text { and Leather }\end{array}$ & 8 & 14.0 & 14.0 & 70.2 \\
\cline { 2 - 6 } & $\begin{array}{c}\text { Electricals and } \\
\text { electronics }\end{array}$ & 8 & 14.0 & 14.0 & 84.2 \\
\cline { 2 - 6 } & $\begin{array}{c}\text { General } \\
\text { Machinery }\end{array}$ & 9 & 15.8 & 15.8 & 100.0 \\
\cline { 2 - 6 } & Total & 57 & 100.0 & 100.0 & \\
\hline
\end{tabular}

Table 2: EM Policy Communication

\begin{tabular}{|c|c|c|c|c|c|}
\hline \multicolumn{2}{|c|}{} & Frequency & Percent & $\begin{array}{c}\text { Valid } \\
\text { Percent }\end{array}$ & $\begin{array}{c}\text { Cumulative } \\
\text { Percent }\end{array}$ \\
\hline \multirow{5}{*}{ Valid } & Posted at facility & 27 & 47.4 & 47.4 & 47.4 \\
\cline { 2 - 6 } & $\begin{array}{c}\text { Distributed to } \\
\text { employees }\end{array}$ & 4 & 7.0 & 7.0 & 54.4 \\
\cline { 2 - 6 } & $\begin{array}{c}\text { Verbal } \\
\text { Communication }\end{array}$ & 14 & 24.6 & 24.6 & 78.9 \\
\cline { 2 - 6 } & None & 12 & 21.1 & 21.1 & 100.0 \\
\cline { 2 - 6 } & Total & 57 & 100.0 & 100.0 & \\
\hline
\end{tabular}

Questions regarding environmental audits were divided into two categories, such as external and internal audits. Talking about external environmental audits, $54.4 \%$ of them said that they had it 1-2 times per financial year. Besides that, $24 \%$ of the respondents said they never had any external environmental audits. Only $3.5 \%$ of the respondents had 3 to 4 external environmental audits per financial year. When questioned about the frequency of internal environmental audits, based on table 12, 37 out of 57 respondents said they've had at least 1 to 2 internal audits per financial year followed by 11 respondents saying 3 to 4 times, and 9 respondents saying none. Table 4 shows the result for both external and internal audit.

Table 3: Mode of EM Policy Communication by nature of business

\begin{tabular}{|c|c|c|c|c|c|c|}
\hline & \multicolumn{4}{|c|}{ Mode of EM Policy Communication } & \multirow[t]{2}{*}{ Total } \\
\hline & & Posted at facility & Distributed to employees & Verbal Communication & None & \\
\hline \multirow{7}{*}{$\begin{array}{c}\text { Business } \\
\text { Nature }\end{array}$} & Automotive & 2 & 1 & 1 & 0 & 4 \\
\hline & Petroleum, Chemicals, and plastics & 5 & 1 & 7 & 1 & 14 \\
\hline & Food Production & 4 & 1 & 2 & 1 & 8 \\
\hline & Metal Manufacturing & 4 & 0 & 1 & 1 & 6 \\
\hline & Wood, Paper, and Leather & 5 & 0 & 1 & 2 & 8 \\
\hline & Electricals and Electronics & 4 & 1 & 0 & 3 & 8 \\
\hline & General Machinery & 3 & 0 & 2 & 4 & 9 \\
\hline & Total & 27 & 4 & 14 & 12 & 57 \\
\hline
\end{tabular}




\section{International Journal of Science and Research (IJSR) \\ ISSN (Online): 2319-7064}

Index Copernicus Value (2013): 6.14 | Impact Factor (2014): 5.611

Table 4: External vs Internal Audit

\begin{tabular}{|c|c|c|c|c|c|c|c|c|c|}
\hline \multicolumn{2}{|c|}{} & \multicolumn{2}{c|}{ Frequency } & \multicolumn{2}{c|}{ Percent } & \multicolumn{2}{c|}{ Valid Percent } & \multicolumn{2}{c|}{ Cumulative Percent } \\
\cline { 2 - 11 } \multicolumn{2}{|c|}{} & External & Internal & External & Internal & External & Internal & External & Internal \\
\hline \multirow{4}{*}{ Valid } & $1-2$ times & 31 & 37 & 54.4 & 64.9 & 54.4 & 64.9 & 54.4 & 64.9 \\
\cline { 2 - 11 } & $3-4$ times & 2 & 11 & 3.5 & 19.3 & 3.5 & 19.3 & 57.9 & 84.2 \\
\cline { 2 - 11 } & None & 24 & 9 & 42.1 & 15.8 & 42.1 & 15.8 & 100.0 & 100.0 \\
\cline { 2 - 11 } & Total & 57 & 57 & 100.0 & 100.0 & 100.0 & 100.0 & & \\
\hline
\end{tabular}

The next question in this section focuses on environmental training received by subject's employees by department. Respondents were required to indicate the frequency by department such as purchasing, sales, engineering, maintenance, operation, and management. Most respondents said that none of their employees from various department received environmental training over the past 12 months. The second famous option is 1-10 employees each department followed by 11-20 employees, and the least chosen option is 31 and above. Highest number of environmental training were carried out in the operations department. Table 5 shows the result.

Table 5: Environmental Training by Department

\begin{tabular}{|c|c|c|c|c|c|}
\hline & $\begin{array}{c}1-10 \\
\text { times }\end{array}$ & $\begin{array}{c}11-20 \\
\text { times }\end{array}$ & $\begin{array}{c}21-30 \\
\text { times }\end{array}$ & $\begin{array}{c}31 \text { and } \\
\text { above }\end{array}$ & None \\
\hline Purchasing & 19 & 7 & - & - & 31 \\
\hline Sales & 20 & 6 & - & - & 31 \\
\hline Engineering & 13 & 5 & - & - & 39 \\
\hline Maintenance & 31 & 9 & - & - & 17 \\
\hline Operation & 11 & 6 & 13 & 19 & 8 \\
\hline Management & 36 & 10 & - & - & 11 \\
\hline
\end{tabular}

One of the keys to identify the subject's environmental management practices, is to know if they have ISO 14001 (Environmental Management) policy certification. Most of the respondents said that they are planning to implement EM policy (25 responses $/ 43.9 \%$ ). Not considered' and Future
Consideration' share a percentage of $17.5 \%$ each. ISO 14001 is successfully implemented by $15.8 \%$ subjects and currently being implemented by $5.3 \%$ subjects. The highest number of ISO 14001 certifications are from petroleum, chemicals, and plastics, food production, wood, paper, and leather, electrical, and electronics sectors with an equal share of $16.7 \%$ each. The rest are equally shared by automotive, general machinery, and metal manufacturing. Table 6 represents the result obtained.

\subsection{Relations with Stakeholders}

There are EM events organized by government and NGO. Table 7 shows the participation in government programs by sectors. Most number of participations are from petroleum, chemicals, and plastics sector and the most inactive sector is general machinery

On the other hand, Table 8 shows the participation in NGO and industry-led programs in general. Almost $42.1 \%$ of the respondents said that they never participate in such programs, while $10.5 \%$ chose Frequent". Almost more than half $(52.6 \%)$ of the respondents said they never participate in such programs. Only $17.5 \%$ and $8.8 \%$ of respondents said they sometimes participate and frequently participate, respectively

Table 6: ISO14001 Status

\begin{tabular}{|c|c|c|c|c|c|}
\hline & & Frequency & Percent & Valid Percent & Cumulative Percent \\
\hline \multirow{4}{*}{ Valid } & Not considered & 10 & 17.5 & 17.5 & 17.5 \\
\cline { 2 - 6 } & Future consideration & 10 & 17.5 & 17.5 & 35.1 \\
\cline { 2 - 6 } & Planning to implement & 25 & 43.9 & 43.9 & 78.9 \\
\cline { 2 - 6 } & Currently Implementing & 3 & 5.3 & 5.3 & 84.2 \\
\cline { 2 - 6 } & Successfully Implemented & 9 & 15.8 & 15.8 & 100 \\
\cline { 2 - 6 } & Total & 57 & 100 & 100 & \\
\hline
\end{tabular}

Table 7: Participation in Government programs by sectors

\begin{tabular}{|c|c|c|c|c|c|}
\hline & \multicolumn{4}{|c|}{ Government events } & \multirow{2}{*}{ Total } \\
\cline { 2 - 5 } & Frequent & Sometimes & Barely participate & Never participate & \\
\hline Automotive & 0 & 2 & 1 & 1 & 4 \\
\hline Petroleum, Chemicals, and plastics & 3 & 7 & 2 & 2 & 14 \\
\hline Food Production & 1 & 2 & 5 & 0 & 8 \\
\hline Metal Manufacturing & 1 & 2 & 2 & 1 & 6 \\
\hline Wood, Paper, and Leather & 2 & 4 & 1 & 1 & 8 \\
\hline Electricals and electronics & 2 & 3 & 1 & 2 & 8 \\
\hline General Machinery & 1 & 2 & 2 & 4 & 9 \\
\hline Total & 10 & 22 & 14 & 11 & 57 \\
\hline
\end{tabular}




\section{International Journal of Science and Research (IJSR) \\ ISSN (Online): 2319-7064}

Index Copernicus Value (2013): 6.14 | Impact Factor (2014): 5.611

Table 8: Subject's participation in NGO and industry-led programs

\begin{tabular}{|c|c|c|c|c|c|c|c|c|c|}
\hline \multicolumn{2}{|c}{} & \multicolumn{2}{c|}{ Frequency } & \multicolumn{2}{c|}{ Percent } & \multicolumn{2}{c|}{ Valid Percent } & \multicolumn{2}{c|}{ Cumulative Percent } \\
\cline { 3 - 11 } \multicolumn{2}{c|}{} & NGO & Industry-led & NGO & Industry-led & NGO & Industry-led & NGO & Industry-led \\
\hline \multirow{4}{*}{ Valid } & Frequent & 6 & 5 & 10.5 & 8.8 & 10.5 & 8.8 & 10.5 & 8.8 \\
\cline { 2 - 11 } & Sometimes & 16 & 10 & 28.1 & 17.5 & 28.1 & 17.5 & 38.6 & 26.3 \\
\cline { 2 - 11 } & Barely participate & 11 & 12 & 19.3 & 21.1 & 19.3 & 21.1 & 57.9 & 47.4 \\
\cline { 2 - 10 } & Never participate & 24 & 30 & 42.1 & 52.6 & 42.1 & 52.6 & 100 & 100 \\
\cline { 2 - 10 } & Total & 57 & 57 & 100 & 100 & 100 & 100 & & \\
\hline
\end{tabular}

The questionnaire also tested subject's view on soliciting opinions from non-profit organization (NPOs), such as involving them identifying and resolving environmental issues. This question garnered a very good positive response (84.2\%). Only $15.8 \%$ of the respondents said Maybe" to this question. With none of the respondents choosing No' to this question, the possibilities of manufacturing industries to work together with NPOs to improve their environmental performance seems to be bright.

The last question in this section of the questionnaire discusses the group of people that influences the subject's improvement in environmental performance. The group of people that asked to rate according to their influence are customers, Government, NGOs, suppliers, shareholders, local community, competitors, members of the industry, and employees. The group that is said to be very influential in subject's improvisation of environmental performance is Government and the least is the local community.

Since this is a Likert scale question, reliability analysis has been done using Cronbach's Alpha. Table 9 shows item statistics of the survey. The scale statistics produced the mean value of 31.33 , variance of 64.048 and standard deviation of 8.003. Cronbach's Alpha is more than 0.7, therefore the data obtained for this question is very reliable.

\subsection{Environmental Performance}

Since this section of the questionnaire tested the respondent $s$ environmental awareness, the first question is about environmental issues they face or they observe in their surroundings. Result in Table 10 shows the most common type of environmental issue recorded is air pollution, with $89.5 .4 \%$.

The following questions ask subject's opinion on critical factors that affect the effective implementation of Environmental Management. Table 11 shows the critical factors. Employee's behaviour is chosen to be most important critical factor with $96.5 \%$.

Table 9: Item Statistics

\begin{tabular}{|c|c|c|c|c|c|c|c|}
\hline & Mean & $\begin{array}{c}\text { Std. } \\
\text { Deviation }\end{array}$ & $\mathrm{N}$ & $\begin{array}{c}\text { Scale Mean if } \\
\text { Item Deleted }\end{array}$ & $\begin{array}{c}\text { Scale Variance if } \\
\text { Item Deleted }\end{array}$ & $\begin{array}{c}\text { Corrected Item- } \\
\text { Total Correlation }\end{array}$ & $\begin{array}{c}\text { Cronbach's Alpha if } \\
\text { Item Deleted }\end{array}$ \\
\hline Customers & 4.12 & 1.181 & 57 & 27.21 & 50.348 & .734 & .902 \\
\hline Government & 4.35 & .991 & 57 & 26.98 & 51.982 & .776 & .900 \\
\hline NGOs & 4.16 & 1.031 & 57 & 27.18 & 52.576 & .696 & .905 \\
\hline Suppliers & 3.18 & 1.241 & 57 & 28.16 & 48.778 & .792 & .897 \\
\hline Shareholders & 3.35 & 1.157 & 57 & 27.98 & 50.053 & .773 & .899 \\
\hline Local_community & 2.60 & 1.400 & 57 & 28.74 & 50.519 & .581 & .915 \\
\hline Competitors & 3.89 & 1.113 & 57 & 27.44 & 50.501 & .778 & .899 \\
\hline industry_members & 3.60 & 1.033 & 57 & 27.74 & 51.662 & .763 & .900 \\
\hline Employees & 2.09 & 1.199 & 57 & 29.25 & 53.939 & .492 & .919 \\
\hline
\end{tabular}

Table 10: Environmental Issue

\begin{tabular}{|c|c|c|c|c|}
\hline & \multicolumn{2}{|c|}{ Responses } & \multirow{2}{*}{$\begin{array}{l}\text { Percent of } \\
\text { Cases }\end{array}$} \\
\hline & & $\mathrm{N}$ & Percent & \\
\hline \multirow{5}{*}{ Valid } & Air Pollution & 51 & $27.4 \%$ & $89.5 \%$ \\
\hline & Water Pollution & 35 & $18.8 \%$ & $61.4 \%$ \\
\hline & Solid Waste & 46 & $24.7 \%$ & $80.7 \%$ \\
\hline & Hazardous Waste & 15 & $8.1 \%$ & $26.3 \%$ \\
\hline & Noise Pollution & 39 & $21.0 \%$ & $68.4 \%$ \\
\hline & Total & 186 & $100.0 \%$ & $326.3 \%$ \\
\hline
\end{tabular}

Table 11: Critical Factors

\begin{tabular}{|c|c|c|c|c|}
\hline \multicolumn{2}{|c|}{} & \multicolumn{2}{|c|}{ Responses } & Percent of \\
\cline { 3 - 4 } \multicolumn{2}{c|}{} & $\mathrm{N}$ & Percent & Cases \\
\hline \multirow{4}{*}{$\$ \mathrm{CF}^{\mathrm{a}}$} & Financial Restrictions & 35 & $25.7 \%$ & $61.4 \%$ \\
\cline { 2 - 5 } & Company Policy & 21 & $15.4 \%$ & $36.8 \%$ \\
\cline { 2 - 5 } & Human Power & 25 & $18.4 \%$ & $43.9 \%$ \\
\cline { 2 - 5 } & Employees' Behaviour & 55 & $40.4 \%$ & $96.5 \%$ \\
\hline \multicolumn{2}{|c|}{ Total } & 136 & $100.0 \%$ & $238.6 \%$ \\
\hline
\end{tabular}

The upcoming question is asked to obtain subject's opinion regarding how they can overcome the challenges in practicing Environmental Management successfully. All 3 of the given options garnered an equal response of $94.7 \%$ each. Table 12 shows the result obtained.

Table 12: Overcoming Challenges

\begin{tabular}{|c|c|c|c|c|}
\hline \multicolumn{2}{|c|}{} & \multicolumn{2}{|c|}{ Responses } & Percent \\
\cline { 3 - 4 } & & $\mathrm{N}$ & Percent & of Cases \\
\hline \multirow{4}{*}{$\begin{array}{c}\text { Overcome } \\
\text { Challenges }\end{array}$} & \begin{tabular}{c} 
Train Employees \\
\cline { 2 - 4 }
\end{tabular} & 54 & $33.3 \%$ & $94.7 \%$ \\
\cline { 2 - 4 } & $\begin{array}{c}\text { Warticipate in environmental } \\
\text { Programs }\end{array}$ & 54 & $33.3 \%$ & $94.7 \%$ \\
\hline $\begin{array}{c}\text { Government, NGOs, and } \\
\text { NPOs }\end{array}$ & 54 & $33.3 \%$ & $94.7 \%$ \\
\hline \multicolumn{2}{|c|}{ Total } & 162 & $100.0 \%$ & $284.2 \%$ \\
\hline
\end{tabular}




\section{International Journal of Science and Research (IJSR) \\ ISSN (Online): 2319-7064}

Index Copernicus Value (2013): 6.14 | Impact Factor (2014): 5.611

The last question in the questionnaire is about subject's opinion on implementation of Environmental Management's direct or indirect effect on production. About 52 respondents said YYes' to this question, which yields a percentage of $91.2 \%$. Only an $8.8 \%$ respondents said No' to this question. The responses shows that the industry has positive view on Environmental Management Policy.

\section{Discussion}

Based on the result, the target respondents were mostly occupying middle or higher position of the manufacturing company. They have more exposure and knowledge of environmental management practices and behaviour of a manufacturing company which makes the data obtained very reliable.

Most companies has full-time employees working on the safety and health issues of the facility instead of environmental specialist or engineers. When inquired on this, the sole reason given by the respondents was financial restrictions of the organization that doesn't have the capability to specially hire an environmental engineer or specialist.

A company should undergone environmental audits regularly, and the company's management should review it from time to time to make sure that its effective and adequate (Jesús Ángel del Brío, 2001). A manager's attitude towards environment will directly or indirectly influence their attitude towards SME green concept (Peter Yacob, June 2012).

Based on the data, the participation of SME manufacturing companies in environmental programs organized by local city council or authorities, NGOs, and the industry members themselves is very poor. The survey results clearly shows how vital is the role of Government authorities and NGOs in influencing a company's environmental behaviour and practices and the respondents were also very well aware of that. Observations made prior to the survey helped to come up with a list of environmental issues.

Effective implementation of EM also means that an organization should overcome some of the challenges. They must first identify the critical factors that affects implementation of environmental management. As discussed earlier, financial restriction have always been a hurdle for SMEs in the process of inducing environmental policies. Moreover, the survey also identified that employee's behaviour is also another important critical factors. Training the employees, working closely with stakeholders such as government agencies, NGOs, and participating in environmental programs are some of the elements for improving environmental performance and compliance (Commission for Environmental Cooperation, 2000).

\section{Conclusion}

Some very valuable data in regards with Environmental Management in small and medium scale manufacturing industries in Shah Alam have been gathered via this research.
Some of the assumptions and observations made prior to the survey are proven to be accurate, as it is strongly backed by the survey results. For instance, SME manufacturing do lag far behind compared to other industries in implementing EM. Besides that, this research enabled us to understand the behaviour and practices of SME manufacturing industries in Shah Alam towards the environment. Government and NGOs are found to be playing an important role in the environmental performance of these companies. The implementation of EM is a continuous effort which requires constant aid in the form of advice and knowledge sharing. At the end of this research, we were able to provide with some recommendations and measures for effective implementation of Environmental Management is provided. Overall, the objectives of this research have been achieved.

\section{References}

[1] SME Corp. Malaysia. 2013. Guidelines For New SME Definition. SME Corp. Malaysia.

[2] Ambika Zutshia, Amrik Sohal. 2004. "A study of the environmental management system (EMS) adoption process within Australasian organisations-2. Role of stakeholders." Technovation 371-386.

[3] Commission for Environmental Cooperation. 2000. Improving Environmental Performance and Compliance: 10 Elements of Effective Environmental Management Systems. Montreal: Commission for Environmental Cooperation.

[4] H. H. Low, O. K. Tan, S. L. Choi, and A. R. Rabeatul Husna. 2015. "The Adoption of Environmental Management System in Malaysia's Manufacturing Organizations." Journal of Economics, Business and Management 93-97.

[5] H.J.D. Vries, D.K. Bayramoglu, T.V Wiele. 2012. "Business and environmental impact of ISO 14001." International Journal of Quality \& Reliability Management 425 - 435.

[6] Homens, J.L.M. 2011. Labeling Schemes or Labeling Scams? Auditors' Perspectives on ISO 14001 Certification. Blacksburg: faculty of the Virginia Polytechnic Institute and State University.

[7] Jesús Ángel del Brío, Esteban Fernández, Beatriz Junquera andCamilo José Vázquez. 2001. "Motivations for Adopting the ISO 14001 Standard: A Study of Spanish Industrial Companies." Environmental Quality Management 10 (4): 13-28.

[8] Nalini, G. and Bonnie, F.D. 2004. "Motivating employees for environmental improvement." Industrial Management \& Data System 364-372.

[9] O. Boiral, J.F. Henri. 2012. "Modelling the impact of ISO 14001 on environmental performance: A Comparative Approach." Journal of Environmental Managemen 84-97.

[10] Oliver Ling Hoon Leh, Siti Nur Afiqah Mohamed Musthafa and Noralizawati Mohamed. 2014. "Air Quality and Land Use in Urban Region of Petaling Jaya,." Environmental Asia 134-144.

[11]P. Gonzalez, J. Sarkis, B. Adenso-Diaz. 2008. "Environmental management system certification and its influence on corporate practices: Evidence from the 


\section{International Journal of Science and Research (IJSR) \\ ISSN (Online): 2319-7064}

Index Copernicus Value (2013): 6.14 | Impact Factor (2014): 5.611

automotive industry." International Journal of Operations \& Production Management 1021 - 1041.

[12] Perumal Puvanasvaran, Robert Kerk Swee Tian, Vasu Suresh, Mohd Razali Muhamad. 2012. "Lean principles adoption in environmental management system (EMS): A survey on ISO 14001 certified companies in Malaysia." Journal of Industrial Engineering and Management 406-430.

[13]Peter Yacob, M.Krishna Moorthy. June 2012. "Green Practices: Perception of Malaysian SME Owners/Managers." International Journal of Academic Research in Economics and Management Sciences 1 (3): 103-111.

[14] Peter Yacob, Nur Syaheeda Binti Aziz, Mohamad Fared bin Mohamad Makmur, Adi Wira bin Mohd Zin. 2013. "The policies and green practices of Malaysian SMEs." Global Business and Economics Research 23-65.

[15] Philip J. Stapleton, Margaret A. Glover, S. Petie Davis. 2001. Environmental Management Systems: An Implementation Guide for Small and Medium-Sized Organizations. Ann Arbor, Michigan: NSF International

[16]S.S.Chen. 2000. ENVIRONMENTAL ISSUES OF MALAYSIA. Shah Alam: Sirim Berhad.

[17] The National Environmental Education \& Training Foundation. 2001. Standardizing Excellence: Working with Smaller Businesses to Implement Environmental Management Systems. Guidance, Washington DC: The National Environmental Education \& Training Foundation.

[18] UCLA. 2015. IDRE. July 11. http://www.ats.ucla.edu/stat/spss/faq/alpha.html. 